\title{
The control of composition, texture and weathering on the physical and strength properties of selected intrusive igneous rocks from North Pakistan
}

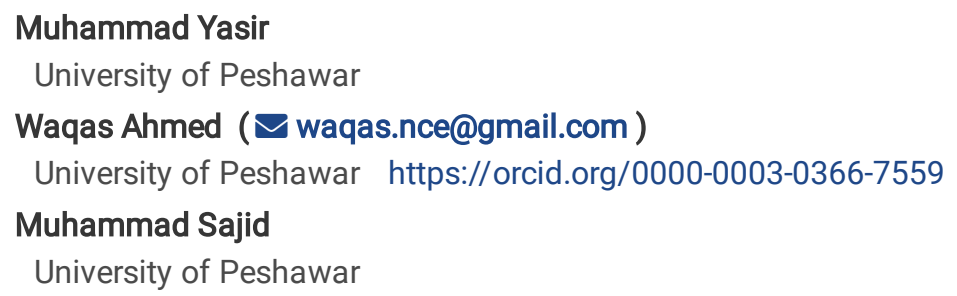

License: () (1) This work is licensed under a Creative Commons Attribution 4.0 International License. Read Full License 


\section{Abstract}

This work characterizes intrusive igneous rocks from north Pakistan in terms of their mineralogy, texture and weathering grades and their effect on the physical and strength properties. The mafic and intermediate rocks showed a low cumulative percentage of quartz, feldspar and plagioclase with high specific gravity, strength (i.e. UCS and R-value) and UPV values compared to the felsic rocks. Likewise, samples with anhedral grain shape, irregular boundaries, fine to medium grain size (UD, ANS, CGN) showed higher strength values, that is, 121,118 and $91 \mathrm{MPa}$ compressive strength and 11, 9, and $12 \mathrm{MPa}$ tensile strengths, respectively. The weathering grades assigned to the investigated samples, such as fresh (WG-I), slightly weathered (WG-II) and highly weathered (WG-III) corresponded well with the physical and strength properties, that is, as the grade increased from WG-I to WG-III, the porosity and water absorption increased $(0.28 \%$ and $0.72 \%$ respectively), whereas the specific gravity, compressive strength and tensile strength decreased $(2.04,20 \mathrm{MPa}$ and $2.5 \mathrm{MPa}$, respectively, for CGA). The presence of quartz affects rock strength; however, no significant correlation was observed for strength and maximum and mean grain sizes of different minerals.

\section{Introduction}

Rocks, whether igneous, sedimentary, or metamorphic, have been used as a construction material throughout human history. Strength and durability of rocks are the two key parameters that require evaluation before their selection as construction material and dimension stone. Studies have shown that in addition to the composition, several petrographic features control rock strength and the stress and strain behavior of rock, such as modal abundance, texture and grain size distribution (Arif et al. 1999; Sajid et al. 2016; Sousa 2013). Moreover, weathering and alteration also influence the rock strength and durability (Coggan et al. 2013; Tuğrul 2004).

The mechanical properties of different textural varieties of Utla granites from north-west Pakistan were investigated (Sajid and Arif 2015). It was observed that reduction in the strength is linked to the extensive recrystallization and associated mineralogical changes. Altered parts of minerals and petrological features such as exsolution in mineral phases can induce compressional fractures under loading (Coggan et al. 2013). As a general trend, fine-grained rocks show higher strength compared to their coarse-grained counterparts. However, with increasing complexity in texture (variation in grain size, shape and boundary), the strength also increases (Åkesson et al. 2003; Lindqvist et al. 2007; Tuğrul and Zarif 1999). Lindqvist et al. (2007) noticed that minerals with euhedral grains (regular boundaries) serve as discontinuities in a rock structure that facilitates fracture growth. The textural variations affect other properties such as resistance to drilling penetration and thermal wear (Howarth and Rowlands 1986). Studies show that micro-textures and fractures affect rock weathering and are primarily responsible for the changes in the physical and mechanical properties (Coggan et al. 2013; Rigopoulos et al. 2010; Sajid and Arif 2015; Sajid et al. 2016).

The northern part of Pakistan consists of Indian Plate, Kohistan Island Arc (KIA) and Eurasian Plate (Coward et al. 1986; Tahirkheli 1979). The Indian Plate consists of several intrusive igneous rocks that can be proposed as quality construction materials such as Mansehra Granite, Malakand Granite, Utla Granite, Ambela Granite, Chakdara Granite, Swat Granite and some dolerites in the form of dykes. The textural and weathering controls on mechanical behavior for a particular rock type have been elaborated in detail (Rigopoulos et al. 2010; Sajid et al. 2016). This study, in contrast, highlights the effects of common textural observation, derived from various rock units, on the mechanical nature of rocks. For this purpose, the geochemically and texturally different intrusive rocks from north Pakistan were investigated and the role of texture and weathering on their physical and strength properties was discussed. Petrography, physical tests (specific gravity, water absorption, porosity, Ultrasonic Pulse Velocity-UPV) and strength tests (compressive, tensile, Schmidt hammer rebound-R-value) were performed. Finally, the relationships of petrographic and engineering properties of these rocks were also statistically modeled and evaluated.

\section{Materials And Methods}

Fieldwork was conducted to collect bulk samples from Utla Dolerite (UD), Nepheline Syenite (ANS), Chilas Gabbronorite (CGN), Ambela Granite (AG), Chakdara Granite (CGB), Swat Granite (SG), and Chakdara Granite (CGA) (Fig. 1). The samples were collected based on texture, weathering-grade and mesoscopic structures (Table 1). The weathering condition was assessed, based on a careful examination of rocks in terms of the original texture preserved, the color of the fresh and weathered surfaces and impact sound produced by the geologic hammer (Borrelli et al. 2007; Irfan and Dearman 1978). Indicators of weathering, such as fractures, recrystallization and alteration of different minerals were also noticed. Figure 2 shows cylindrical core specimens (50-mm diameter) obtained from the investigated rock types to perform the physical and strength tests. The tests were conducted on three core specimens from each rock sample and average results are reported. Thin-sections were prepared from small chips of cores (size $40 \times 20 \mathrm{~mm}$ ) for the petrographic 
study. The petrographic examination included both the naked eye and microscopic observations. Thin-sections from each sample were studied under the polarizing microscope (Nikon Eclipse LV100ND). Minerals were identified based on their optical properties (MacKenzie and Guilford 2014). The modal abundance was determined (based on visual estimation) and grain shape, size and arrangements were noted for textural identification.

The physical property tests such as specific gravity and water absorption were determined in the laboratory according to standard test methods for absorption and bulk-specific gravity of dimension stone (ASTM, DC97 / C97M-18). The porosity of the investigated rocks was obtained using the saturation method (Franklin 1979). The UPV was determined using the ultrasonic pulse velocity test instrument from MS CONTROLS Italy. A pitch-catch technique was used that involves a pair of transducers i.e. transmitter and receiver (Aydin 2013). The frequency of $10 \mathrm{~s}^{-1}$ was used to acquire the transit travel time of the core samples at two conditions i.e. saturated surface dry $\left(\mathrm{UPV}_{\mathrm{SSD}}\right)$ and the oven-dry $\left(\mathrm{UPV}_{\mathrm{OD}}\right)$ at $110^{\circ} \mathrm{C}$ for $24 \mathrm{~h}$. To obtain better correlations, all the tests were conducted on the same specimen that was later used for the strength tests.

The Unconfined Compressive Strength, (UCS) test was conducted according to the standard test methods for compressive strength and elastic moduli of intact rock core specimens under varying states of stress and temperatures (ASTM, D7012-14e1). Unconfined Tensile Strength (UTS) test was performed using a Brazilian test method according to the standard test method for splitting tensile strength of intact rock core specimens (ASTM, D3967-16). The Schmidt hammer rebound test (R-value) is a nondestructive method for determining the strength and was conducted according to the standard test method for determination of rock hardness by a rebound hammer method (ASTM, D5873-14). The R-value was obtained using N-type Schmidt Hammer (SH) equipment having impact energy $0.735 \mathrm{Nm}$

\section{Results}

\subsection{Petrography and Weathering Grades:}

Figure 3 shows the selected microphotographs of the investigated rocks and Table 1 shows their petrographic description. Table 2 shows the modal mineralogy and average grain size. Based on the modal mineralogy, the rocks are classified as mafic (UD, CGN) intermediate (ANS,) and felsic (AG, CGB, SG, CGA). Tables 3 presents weathering grades (WG) assigned to the investigated rocks based on field and microscopic observations. The rocks were classified as fresh, WG-I (UD, ANS and CGN), slightly weathered, WG-II (AG, CGB and SG) and highly weathered, WG-III (CGA).

\subsection{Physical Properties}

Table 4 enlists the average results of physical properties. Fresh, WG- I samples (UD, ANS and CGN) showed higher specific gravity, and $\mathrm{UPV}_{\text {sat }}(3.08$ and $5573.17 \mathrm{~m} / \mathrm{sec}$ respectively for UD), and lower WA $(0.13 \%$ for CGN) and porosity $(0.12 \%$ for ANS). The highly weathered sample, WG-III, (CGA) showed the minimum specific gravity (2.04) and UPV dry $_{1}(1526.26 \mathrm{~m} / \mathrm{sec})$, and the maximum water absorption (WA) $(0.28 \%)$ and porosity $(0.72 \%)$. The results of UPV displayed a slight decrease from UPV sat $_{\text {to }}$ UPV $V_{\text {dry }}$, except for CGA, that displayed a slight increase. These results agree with previous studies on weathering effects on granites that showed a material with high porosity can retain more water and thereby results in reduced UPV values (Sousa et al. 2005; Vasconcelos et al. 2008).

\subsection{Strength Properties}

The strength values of the investigated rocks followed the physical properties (Table 4), i.e. fresh, WG-I samples showed higher UCS (120 MPa for UD) and UTS values (12.40 MPa for CGN). Whereas highly weathered, WG-III sample showed lower UCS and UTS values (20 $\mathrm{MPa}$ and $2.5 \mathrm{MPa}$, respectively, for CGA). These results are comparable with those reported in previous studies from Pakistan (Arif et al. 1999; Rafiq et al. 1988; Sajid and Arif 2015; Sajid et al. 2016) and from various parts of the world such as (Basu et al. 2009; Sousa 2013; Tuğrul 2004). Likewise, high R-value was obtained for fresh, WG-I sample (53.78 for UD) and lowest for highly weathered, WG-III sample (13.67 for CGA).

\subsection{Petrographic, Physical and Strength Properties}

The petrographic, physical and strength properties of the investigated rock varieties are discussed. 
- Sample UD contained a relatively high number of opaque minerals (5\%-8\%), that resulted in a higher specific gravity (3.08). Likewise, the higher porosity $(0.37 \%)$ was attributed to the slight alteration of pyroxene mineral (Fig. 3a) and intergranular fractures. Among the investigated samples, fresh, WG-I sample, UD showed the highest UCS and UTS values (121 MPa and $11 \mathrm{MPa}$, respectively).

- The sample ANS showed a slight alteration of alkali feldspar and amphibole that resulted in relatively high water absorption and porosity values $(0.19 \%$ and $0.12 \%$, respectively). However, it also displayed high UCS and UTS values (i.e. $118 \mathrm{MPa}$ and $9 \mathrm{MPa}$, respectively) and fresh weathering-grade (WG-I). This is attributed to the inequigranular, anhedral grains, irregular grain boundaries mainly of fine-grained feldspar surrounding the nepheline (Fig. 3b).

- The sample CGN showed a uniform grain size and regular boundaries. The twinning and slight alteration (Fig. 3c) resulted in moderate values of water absorption and porosity (i.e. $0.13 \%$ and $0.28 \%$, respectively) and lower UCS and UTS values (i.e. $91 \mathrm{MPa}$ and $12 \mathrm{MPa}$, respectively) compared with other fresh, WG-I samples.

- In sample AG, the water absorption and porosity were the lowest ( $0.06 \%$ and $0.14 \%$ respectively) among the investigated samples. The subhedral grain shape and the presence of large feldspar grains (up to $10 \mathrm{~mm}$ ) having intra-granular fractures (Fig. 3d) contributed to its moderate UCS and UTS values (i.e., $60 \mathrm{MPa}$ and $6 \mathrm{MPa}$, respectively) and slightly weathered, WG-II weatheringgrade.

- The sample CGB showed relatively fresh grains of alkali feldspar, quartz and mica than CGA (Fig. 3e) and therefore resulted in lower water absorption and porosity ( $0.17 \%$ and $0.44 \%$ respectively), higher UCS and UTS values (i.e. $53 \mathrm{MPa}$ and $6 \mathrm{MPa}$, respectively) and slightly weathered WG-II weathering-grade.

- The sample SG showed gneissosity in the form of aligned flaky mica (Fig. 3f). Besides, it showed gneissosity and slight weathering (WG-II) and resulted in moderate water absorption and porosity ( $0.12 \%$ and $0.26 \%$ respectively). The alteration as sericitization and fractures in alkali feldspar impacted its UCS and UTS values (i.e. $45 \mathrm{MPa}$ and $6 \mathrm{MPa}$, respectively). Åkesson (2004)also made similar observations on microstructures in granites and marbles from Sweden.

- The sample CGA was highly sheared (WG-III) and showed sericitization, alteration and intense fracturing of alkali feldspar (Fig. 3g). As a result, high water absorption and porosity values were obtained $(0.28 \%$ and $0.62 \%$, respectively). It showed the lowest UCS and UTS values among the investigated samples (20 MPa and $3 \mathrm{MPa})$.

\section{Discussion}

Figure 4 shows the regression analysis to investigate the effect of mineralogy and weathering grades of the investigated rocks on the physical and strength properties. The cumulative percentage of quartz, feldspar and plagioclase $(\mathrm{Q}+\mathrm{F}+\mathrm{P})$ is plotted against the specific gravity, UCS, R-value and UPV, and inverse correlations are obtained (Figs. $4 a, b, c)$ with $R^{2} 0.62,0.81$, and 0.90 , respectively. Figure $4 a$ shows the mafic and intermediate rocks, fresh (WG-I) having a lower cumulative percentage of Q+F+P resulted in a higher specific gravity (2.68 to 3.08). Whereas, the felsic rocks, slightly weathered to highly weathered (WG-II and WG-III) having a higher cumulative percentage of Q+F+P showed lower specific gravity (2.0 to 2.67). Rocks having higher specific gravity indicate heavy and high-strength minerals, which have a significant impact on the rock strength (Fig. 4d). These findings are in agreement to (Sajid et al. 2016), who correlated modal composition of quartz, plagioclase and feldspar against the UCS and found negative correlations for quartz and plagioclase but

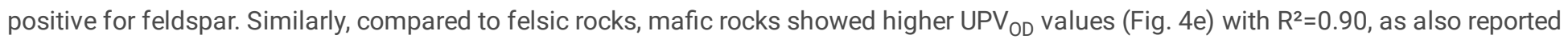
by (Behn and Kelemen 2003).

The ultrasonic pulse velocity (UPV) as an index of rock strength is well explained by (Aldeeky and Al Hattamleh 2018; Ercikdi et al. 2016; Gomez-Heras et al. 2020; Selçuk and Nar 2016). They argued that UPV with detailed petrography can evaluate fractures and compactness in rocks. Yılmaz et al. (2014) found a positive correlation between specific gravity and UPV and showed compact rocks have higher UPV values. Figure 5 a plots UPV and specific gravity with $\mathrm{R}^{2}=0.89$. The compressional waves of UPV show different results

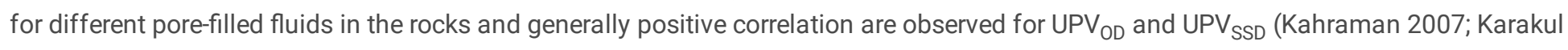
and Ulusay 2013; Vasanelli et al. 2013). Figure $5 b$ shows a positive correlation between $U P V_{O D}$ and $U P V_{S S D}\left(R^{2}=0.87\right)$. Figures $5 c$, and $d$ plot of UPV $O D$ against UCS and R-value and show significant positive correlations, $\left(R^{2}=0.85\right.$ and $R^{2}=0.82$ respectively). These results agree with the findings of Akoglu et al. (2020); Vasanelli et al. (2013); Vasconcelos et al. (2008) who derived similar positive relationships. Figure 5 e shows a positive correlation between the R-value and UCS $\left(R^{2}=0.89\right)$

Figure 6 plots the modal composition and grain size on the rock strength against the UCS. The strength of the rock decreases as the composition changes from mafic to felsic along with the increase in weathering-grade (Fig. 6a). The presence of quartz also affects rock strength, which agrees with the results of (Sajid et al. 2016). The rock strength was plotted against maximum and mean grain sizes of 
different minerals (Fig. 6band C) and no significant correlation was observed which is in contrast to the previous studies by Sajid et al. (2016); Tuğrul (2004) and many others. It can be inferred from these plots that meaningful relationships derived by the previous workers cannot be generalized for any rock type.

\section{Summary And Conclusions}

The details of the field and petrographic observations, geochemical analyses, physical and strength properties of the selected intrusive rocks from north Pakistan are presented in this study. Based on the detailed laboratory testing, the investigated intrusive igneous rocks were categorized as fresh, WG-I (UD, ANS and CGN), slightly weathered, WG-II (AG, CGB and SG) and highly weathered, WG-III (CGA). Physical and strength properties showed a strong relationship with weathering grades. Fresh, WG- I samples (UD, ANS and CGN) showed higher specific gravity, and UPVsat (3.08 and $5573.17 \mathrm{~m} / \mathrm{sec}$ respectively for UD), and lower WA ( $0.13 \%$ for CGN) and porosity ( $0.12 \%$ for ANS). Whereas the highly weathered sample, WG-III, (CGA) showed the minimum specific gravity (2.04) and UPV OD $(1526.26 \mathrm{~m} / \mathrm{sec})$, and the maximum water absorption (WA) $(0.28 \%)$ and porosity (0.72\%). Likewise, fresh, WG-I samples showed higher UCS (120 MPa for UD) and UTS values (12.40 MPa for CGN). While highly weathered, WG-III sample showed lower UCS and UTS values (20 MPa and 2.5 MPa, respectively, for $(G A)$. The ultrasonic pulse velocity of $U P V_{O D}$ slightly decreased compared to $U P V_{S S D}$. The rock strength decreased as the composition changed from mafic to felsic. The presence of quartz also affects rock strength; however, no significant correlation was observed for the rock strength and maximum and mean grain sizes of different minerals. It can be inferred from the results that relationships derived by previous workers cannot be generalized for any other rock type.

\section{Declarations}

\section{Funding}

This research did not receive any specific grant from funding agencies in the public, commercial, or not-for-profit sectors.

Conflicts of interest/Competing interests: The authors certify that they have NO affiliations with or involvement in any organization or entity with any financial or non-financial interest in the subject matter or materials discussed in this manuscript.

Availability of data and material: This work is based on MS thesis; Yasir M (2019). Geomechanical characterization of intrusive rocks from Higher Himalayas and Kohistan Islandarc, North Pakistan. MS Thesis, University of Peshawar. The data is available on request.

Code availability: Not applicable

Authors Contributions: Mr. Muhammad Yasir carried out laboratory testing. Waqas Ahmed drafted the manuscript and provided the conceptual guidance and polished and revised the manuscript. Muhammad Sajid provided the conceptual guidance. All the authors read and approved the final manuscript.

Acknowledgements: The authors would like to acknowledge the National Centre of Excellence in Geology, University of Peshawar (Pakistan), for providing laboratory facilities and field logistics.

\section{References}

Åkesson U (2004) Microstructures in granites and marbles in relation to their durability as a construction material. Dissertation, University of Gothenburg

Åkesson U, Stigh J, Lindqvist JE, Göransson M (2003) The influence of foliation on the fragility of granitic rocks, image analysis and quantitative microscopy. Engineering Geology 68:275-288

Akoglu KG, Kotoula E, Simon S (2020) Combined use of ultrasonic pulse velocity (UPV) testing and digital technologies: A model for long-term condition monitoring memorials in historic Grove Street Cemetery, New Haven. Journal of Cultural Heritage 41:84-95

Aldeeky H, Al Hattamleh $\mathrm{O}$ (2018) Prediction of engineering properties of basalt rock in Jordan using ultrasonic pulse velocity test. Geotechnical and Geological Engineering 36:3511-3525

Arif M, Mulk A, Tariq M, Majid S (1999) Petrography and mechanical properties of the Mansehra granite, Hazara, Pakistan. Geological Bulletin, University of Peshawar 32:41-49

Page 5/15 
Aydin A (2013) Upgraded ISRM suggested method for determining sound velocity by ultrasonic pulse transmission technique. In: The ISRM Suggested Methods for Rock Characterization, Testing and Monitoring: 2007-2014. Springer, pp 95-99

Basu A, Celestino T, Bortolucci A (2009) Evaluation of rock mechanical behaviors under uniaxial compression with reference to assessed weathering grades. Rock Mechanics and Rock Engineering 42:73-93

Behn MD, Kelemen PB (2003) Relationship between seismic P-wave velocity and the composition of anhydrous igneous and metaigneous rocks. Geochemistry, Geophysics, Geosystems 4 doi:10.1029/2002gc000393

Borrelli L, Greco R, Gullà G (2007) Weathering grade of rock masses as a predisposing factor to slope instabilities: reconnaissance and control procedures. Geomorphology 87:158-175

Coggan J, Stead D, Howe J, Faulks C (2013) Mineralogical controls on the engineering behavior of hydrothermally altered granites under uniaxial compression. Engineering Geology 160:89-102

Coward MP et al. (1986) Collision tectonics in the NW Himalayas. Geological Society, London, Special Publications 19:203-219

Ercikdi B, Karaman K, Cihangir F, Yılmaz T, Aliyazıcıoğlu Ş, Kesimal A (2016) Core size effect on the dry and saturated ultrasonic pulse velocity of limestone samples. Ultrasonics 72:143-149

Franklin JA (1979) Suggest methods for determining water content, porosity, density, absorption and related properties and swelling and slake-durability index properties. International Journal of Rock Mechanics and Mining Sciences \& Geomechanics Abstracts 16:141-156

Gomez-Heras M, Benavente D, Pla C, Martinez-Martinez J, Fort R, Brotons V (2020) Ultrasonic pulse velocity as a way of improving uniaxial compressive strength estimations from Leeb hardness measurements. Construction and Building Materials 261:119996

Howarth DF, Rowlands JC (1986) Development of an index to quantify rock texture for qualitative assessment of intact rock properties. Geotechnical Testing Journal 9:169-179

Irfan TY, Dearman WR (1978) Engineering classification and index properties of a weathered granite. Bulletin of the International Association of Engineering Geology-Bulletin de l'Association Internationale de Géologie de l'Ingénieur 17:79-90

Kahraman S (2007) The correlations between the saturated and dry P-wave velocity of rocks. Ultrasonics 46:341-348

Karakul H, Ulusay R (2013) Empirical correlations for predicting strength properties of rocks from P-wave velocity under different degrees of saturation. Rock Mechanics and Rock Engineering 46:981-999

Lindqvist J-E, Åkesson U, Malaga K (2007) Microstructure and functional properties of rock materials. Materials characterization 58:1183-1188

Mackenzie WS, Guilford C (2014) Atlas of the Rock-Forming Minerals in Thin Section. Routledge,

Rafiq M, Khan MA, Jan MQ (1988) Myrmekite In The Ambela Granitic Complex, N. Pakistan, A Product Of Deformation And Replacement In The Feldspar. Journal of Himalayan Earth Sciences 21

Rigopoulos I, Tsikouras B, Pomonis P, Hatzipanagiotou K (2010) The influence of alteration on the engineering properties of dolerites: the examples from the Pindos and Vourinos ophiolites (northern Greece). International Journal of Rock Mechanics and Mining Sciences 47:69-80

Sajid M, Arif M (2015) Reliance of physico-mechanical properties on petrographic characteristics: consequences from the study of Utla granites, north-west Pakistan. Bulletin of Engineering Geology and the Environment 74:1321-1330

Sajid M, Coggan J, Arif M, Andersen J, Rollinson G (2016) Petrographic features as an effective indicator for the variation in strength of granites. Engineering Geology 202:44-54 doi:10.1016/j.enggeo.2016.01.001

Selçuk L, Nar A (2016) Prediction of uniaxial compressive strength of intact rocks using ultrasonic pulse velocity and rebound-hammer number. Quarterly Journal of Engineering Geology and Hydrogeology 49:67-75 
Sousa (2013) The influence of the characteristics of quartz and mineral deterioration on the strength of granitic dimensional stones. Environmental earth sciences 69:1333-1346

Sousa, Del Río LMS, Calleja L, De Argandona VGR, Rey AR (2005) Influence of microfractures and porosity on the physico-mechanical properties and weathering of ornamental granites. Engineering Geology 77:153-168

Tahirkheli RK (1979) The India-Eurasia suture zone in northern Pakistan: synthesis and interpretation of recent data at plate scale. Geodynamics of Pakistan:125-130

Tuğrul A (2004) The effect of weathering on pore geometry and compressive strength of selected rock types from Turkey. Engineering Geology 75:215-227

Tuğrul A, Zarif IH (1999) Correlation of mineralogical and textural characteristics with engineering properties of selected granitic rocks from Turkey. Engineering Geology 51:303-317 doi:https://doi.org/10.1016/S0013-7952(98)00071-4

Vasanelli E, Sileo M, Calia A, Aiello MA (2013) Non-destructive techniques to assess mechanical and physical properties of soft calcarenitic stones. Procedia Chemistry 8:35-44

Vasconcelos G, Lourenco PB, Alves CA, Pamplona J (2008) Ultrasonic evaluation of the physical and mechanical properties of granites. Ultrasonics 48:453-466 doi:10.1016/j.ultras.2008.03.008

Yılmaz T, Ercikdi B, Karaman K, Külekçi G (2014) Assessment of strength properties of cemented paste backfill by ultrasonic pulse velocity test. Ultrasonics 54:1386-1394

\section{Tables}

Table 1 Details of samples collected during the fieldwork

\begin{tabular}{|c|c|c|c|}
\hline Rock Name & $\begin{array}{l}\text { Rock } \\
\text { Designation }\end{array}$ & $\begin{array}{l}\text { Grain } \\
\text { Size }\end{array}$ & Petrographical description \\
\hline Utla Dolerite & UD & Medium & $\begin{array}{l}\text { Equigranular, euhedral to anhedral, ophitic to sub ophitic. Plagioclase was tabular and } \\
\text { showed a typical polysynthetic twinning. Pyroxene (mostly clinopyroxene) was subhedral } \\
\text { to anhedral and sericitized at places. }\end{array}$ \\
\hline $\begin{array}{l}\text { Nepheline } \\
\text { Syenite }\end{array}$ & ANS & Fine & $\begin{array}{l}\text { Inequigranular, anhedral to euhedral grains. Alkali feldspar appeared both as perthite and } \\
\text { microcline. Nepheline was euhedral to subhedral. Amphibole was anhedral, mostly } \\
\text { disseminated and altered. }\end{array}$ \\
\hline $\begin{array}{l}\text { Chilas } \\
\text { Gabbronorite }\end{array}$ & CGN & Medium & $\begin{array}{l}\text { Inequigranular, subhedral to anhedral grains. Plagioclase showed polysynthetic twinning } \\
\text { and sericitization at places. Biotite was present along the margins of pyroxene grains. }\end{array}$ \\
\hline $\begin{array}{l}\text { Ambela } \\
\text { Granite }\end{array}$ & $A G$ & Coarse & $\begin{array}{l}\text { Inequigranular with anhedral to subhedral grains. Alkali feldspar was perthitic having } \\
\text { blebs of albite. Microcline feldspar was also present. Quartz showed undulose extinction. }\end{array}$ \\
\hline $\begin{array}{l}\text { Chakdara } \\
\text { Granite-B }\end{array}$ & CGB & $\begin{array}{l}\text { Fine to } \\
\text { medium }\end{array}$ & $\begin{array}{l}\text { Inequigranular, anhedral to subhedral grains. Alkali feldspar was perthitic where } \\
\text { exsolution lamellae were present and contained inclusions of mica and zircon. Quartz } \\
\text { showed undulose extinction. }\end{array}$ \\
\hline Swat Granite & SG & $\begin{array}{l}\text { Medium } \\
\text { to } \\
\text { coarse }\end{array}$ & $\begin{array}{l}\text { Inequigranular, anhedral grains. Minerals alteration and sericitization were commonly } \\
\text { observed. Alkali feldspar contained inclusions of muscovite and quartz. Mica was mostly } \\
\text { in tabular form and aligned. }\end{array}$ \\
\hline $\begin{array}{l}\text { Chakdara } \\
\text { Granite-A }\end{array}$ & CGA & $\begin{array}{l}\text { Fine to } \\
\text { medium }\end{array}$ & $\begin{array}{l}\text { Equigranular, anhedral grains. Alkali feldspar contained inclusions of mica, mostly } \\
\text { microcline and sericitized. Quartz was mostly recrystallized. Amphibole was altered to } \\
\text { muscovite along the margins. }\end{array}$ \\
\hline
\end{tabular}

Table 2 Modal mineralogy of the studied rocks 


\begin{tabular}{|c|c|c|c|c|c|c|c|c|c|c|c|c|c|c|c|c|c|c|c|c|c|}
\hline & UD & & & ANS & & & CGN & & & $A G$ & & & $\mathrm{CGE}$ & & & SG & & & CGA & & \\
\hline Sample & 1 & 2 & 3 & 1 & 2 & 3 & 1 & 2 & 3 & 1 & 2 & 3 & 1 & 2 & 3 & 1 & 2 & 3 & 1 & 2 & 3 \\
\hline Afs & - & - & - & 54 & 56 & 58 & - & - & - & 65 & 62 & 66 & 58 & 53 & 56 & 34 & 31 & 33 & 58 & 56 & 58 \\
\hline $\mathrm{Qz}$ & - & - & - & - & - & - & - & - & - & 13 & 21 & 18 & 33 & 40 & 36 & 41 & 38 & 41 & 35 & 36 & 34 \\
\hline $\mathrm{Pl}$ & 53 & 50 & 51 & 7 & 7 & 6 & 55 & 57 & 54 & 2 & 2 & 2 & 2 & 1 & 3 & 8 & 11 & 9 & 2 & 1 & 2 \\
\hline $\mathrm{Bt}$ & 1 & 1 & 1 & $\mathrm{~T}$ & $\mathrm{~T}$ & $\mathrm{~T}$ & 2 & 3 & 2 & 9 & 5 & 5 & 3 & 2 & 3 & 9 & 12 & 11 & 3 & 2 & 3 \\
\hline Amp & 1 & 2 & 2 & 6 & 4 & 5 & - & - & - & 6 & 2 & 6 & - & - & - & 4 & 5 & 4 & 0 & 2 & 1 \\
\hline Opq & 5 & 8 & 5 & - & - & - & 2 & 4 & 5 & 2 & 3 & 3 & - & - & - & - & - & - & - & - & - \\
\hline Cal & - & - & - & - & - & - & - & - & - & 1 & 2 & - & - & - & - & - & - & - & - & - & - \\
\hline $\mathrm{Chl}$ & - & - & - & - & - & - & - & - & - & - & 1 & $T$ & - & - & - & - & - & - & - & - & - \\
\hline $\mathrm{Rt}$ & - & - & - & - & - & - & - & - & - & - & - & $T$ & - & - & - & - & - & - & - & - & - \\
\hline Spn & - & - & - & 4 & 4 & 3 & - & - & - & - & - & $\mathrm{T}$ & $\mathrm{T}$ & $\mathrm{T}$ & $T$ & - & - & - & - & - & - \\
\hline Nph & - & - & - & 18 & 21 & 19 & - & - & - & - & - & - & - & - & - & - & - & - & - & - & - \\
\hline Aeg & - & - & - & 11 & 8 & 9 & - & - & - & - & - & - & - & - & - & - & - & - & - & - & - \\
\hline$A p$ & - & - & - & $\mathrm{T}$ & $\mathrm{T}$ & $\mathrm{T}$ & - & - & - & - & - & - & - & - & - & - & - & - & - & - & - \\
\hline Zrn & - & - & - & $\mathrm{T}$ & $\mathrm{T}$ & $\mathrm{T}$ & - & - & - & - & - & - & $\mathrm{T}$ & $\mathrm{T}$ & $T$ & - & - & - & - & - & - \\
\hline Ms & - & - & - & - & - & - & - & - & - & - & - & - & 5 & 4 & 4 & 4 & 3 & 2 & 3 & 3 & 2 \\
\hline OPx & - & - & - & - & - & - & 23 & 20 & 21 & - & - & - & - & - & - & - & - & - & - & - & - \\
\hline $\mathrm{CPx}$ & 40 & 39 & 41 & - & - & - & 18 & 17 & 18 & - & - & - & - & - & - & - & - & - & - & - & - \\
\hline Ol & - & - & - & - & - & - & $\mathrm{T}$ & $\mathrm{T}$ & $\mathrm{T}$ & - & - & - & - & - & - & - & - & - & - & - & - \\
\hline $\begin{array}{l}\text { Avg } \\
\text { Grain } \\
\text { Size } \\
(\mathrm{mm})\end{array}$ & \multicolumn{3}{|l|}{0.85} & \multicolumn{3}{|c|}{1.07} & \multicolumn{3}{|c|}{1.12} & \multicolumn{3}{|c|}{4.15} & \multicolumn{3}{|c|}{0.61} & \multicolumn{3}{|c|}{1.03} & \multicolumn{2}{|c|}{0.63} & \\
\hline
\end{tabular}

Afs= alkali feldspar, $\mathrm{Qz}=$ quartz, $\mathrm{Pl}=$ plagioclase, $\mathrm{Bt}=$ biotite, $\mathrm{Amp}=$ amphibole, $\mathrm{Opq}=$ opaque minerals, $\mathrm{Cal}=$ calcite, $\mathrm{RT}=$ rutile and $\mathrm{Spn}=$ sphene, $\mathrm{Nph}=$ nepheline, $\mathrm{Aeg}=$ aegirine, $\mathrm{Ap}=$ apatite and $\mathrm{Zrn}=$ zircon, $\mathrm{Ms}=$ muscovite, $\mathrm{CPx}=$ clinopyroxene, $\mathrm{T}=$ trace

*Minerals abbreviations are according to Whitney and Evans, 2010.

Table 3 Weathering classification of the investigated rocks (after Irfan and Dearman, 1978; Borrelli et al., 2007) 


\begin{tabular}{|c|c|c|c|c|}
\hline $\begin{array}{l}\text { Rock } \\
\text { Designation }\end{array}$ & Outcrop observations & Microscopic observations & $\begin{array}{l}\text { Descriptive } \\
\text { term }\end{array}$ & $\begin{array}{l}\text { Weathering } \\
\text { Grade }\end{array}$ \\
\hline UD & $\begin{array}{l}\text { Dark grey to black in colour, uniform and fine- } \\
\text { grained. Very compact and produced a sharp } \\
\text { sound with a geological hammer }\end{array}$ & $\begin{array}{l}\text { Ophitic to sub-ophitic texture, with } \\
\text { polysynthetic twinning in plagioclase, } \\
\text { was mostly fresh but slight alteration } \\
\text { was observed in pyroxene. }\end{array}$ & Fresh & I \\
\hline ANS & $\begin{array}{l}\text { Fine to medium-grained, grey and no } \\
\text { discolouration. Purely fresh and produced } \\
\text { good sharp sound with a geologic hammer. }\end{array}$ & $\begin{array}{l}\text { Major minerals such as feldspar and } \\
\text { nepheline were fresh but a slight } \\
\text { alteration of amphibole was observed. }\end{array}$ & Fresh & I \\
\hline CGN & $\begin{array}{l}\text { Greyish in colour on fresh while brown on the } \\
\text { weathered surface, medium-grained. Very } \\
\text { hard, having compact sound with a geologic } \\
\text { hammer. }\end{array}$ & $\begin{array}{l}\text { A slight alteration was observed in } \\
\text { plagioclase and pyroxene at places but } \\
\text { overall dominantly consisted of fresh } \\
\text { mineral grains. }\end{array}$ & Fresh & I \\
\hline AG & $\begin{array}{l}\text { Milky white colour with dark greyish } \\
\text { phenocryst, medium-grained, original texture } \\
\text { was preserved. Produced a compact sound } \\
\text { when struck with a geological hammer The } \\
\text { weathered surface colour was brownish-grey. }\end{array}$ & $\begin{array}{l}\text { Minerals with a fresh appearance and } \\
\text { no signs of prominent alteration. Some } \\
\text { fractures in feldspar and quartz were } \\
\text { present. }\end{array}$ & $\begin{array}{l}\text { Slightly } \\
\text { weathered }\end{array}$ & ॥ \\
\hline CGB & $\begin{array}{l}\text { Light brown, fine to medium-grained. Slight } \\
\text { discolouration and moderately foliated. Fairly } \\
\text { compact sound with a geologic hammer. }\end{array}$ & $\begin{array}{l}\text { Comparatively fresh mineral grains to } \\
\text { CGA, however, alteration of feldspar } \\
\text { was observed. }\end{array}$ & $\begin{array}{l}\text { Slightly } \\
\text { weathered }\end{array}$ & ॥ \\
\hline SG & $\begin{array}{l}\text { White in colour, moderately gneissose and } \\
\text { medium to coarse-grained. Slightly fresh, and } \\
\text { produced dull sound with a geological } \\
\text { hammer. }\end{array}$ & $\begin{array}{l}\text { Alteration and sericitization were } \\
\text { observed in both feldspar and micas. } \\
\text { Feldspar was fractured and mica was } \\
\text { mostly aligned. }\end{array}$ & $\begin{array}{l}\text { Slightly } \\
\text { weathered }\end{array}$ & ॥ \\
\hline CGA & $\begin{array}{l}\text { Milky white in colour, fine-grained, having } \\
\text { discolouration. Extremely sheared and } \\
\text { foliated. Produced a dull sound and was } \\
\text { easily breakable with a geologic hammer. }\end{array}$ & $\begin{array}{l}\text { Thin sections appearance was dirty. } \\
\text { Major minerals such as feldspar and } \\
\text { quartz were highly fractured. } \\
\text { Sericitization and alteration were } \\
\text { commonly observed in feldspar and } \\
\text { amphibole. }\end{array}$ & $\begin{array}{l}\text { Highly } \\
\text { weathered }\end{array}$ & III \\
\hline
\end{tabular}

$\mathrm{AG}=$ Ambela Granite, $\mathrm{ANS}=$ Nepheline Syenite, $\mathrm{CGA}=$ Chakdara Granite A, CGB= Chakdara Granite B, CGN= Chilas Gabbronorite, $\mathrm{SG}=$ Swat Granite, UD= Utla Dolerite

Table 4 Average results of physical and strength properties of the investigated rocks

\begin{tabular}{|llllllllll|}
\hline Sample & $\begin{array}{l}\text { Weathering } \\
\text { Grade }\end{array}$ & $\begin{array}{l}\text { Specific } \\
\text { Gravity }\end{array}$ & $\begin{array}{l}\text { Water } \\
\text { Absorption }(\%)\end{array}$ & $\begin{array}{l}\text { Porosity } \\
(\%)\end{array}$ & $\begin{array}{l}\text { UPV }_{\text {sat }} \\
(\mathrm{m} / \mathrm{sec})\end{array}$ & $\begin{array}{l}\mathrm{UPV}_{\text {OD }} \\
(\mathrm{m} / \mathrm{sec})\end{array}$ & $\begin{array}{l}\text { UCS } \\
(\mathrm{MPa})\end{array}$ & $\begin{array}{l}\text { UTS } \\
(\mathrm{MPa})\end{array}$ & $\begin{array}{l}\text { R- } \\
\text { Value }\end{array}$ \\
\hline UD & I & 3.08 & 0.16 & 0.37 & 5573.16 & 5142.38 & 120.70 & 10.50 & 53.78 \\
\hline ANS & I & 2.68 & 0.19 & 0.12 & 4212.15 & 3629.84 & 118.07 & 9.33 & 47.44 \\
\hline CGN & I & 2.92 & 0.13 & 0.28 & 4769.30 & 4558.54 & 91.35 & 12.40 & 44.33 \\
\hline AG & II & 2.67 & 0.06 & 0.14 & 2896.05 & 2463.62 & 59.94 & 6.03 & 35.44 \\
\hline CGB & II & 2.64 & 0.17 & 0.44 & 2360.35 & 2607.63 & 53.31 & 6.07 & 21.11 \\
\hline SG & II & 2.64 & 0.12 & 0.26 & 3209.28 & 2453.99 & 45.02 & 5.60 & 32.78 \\
\hline CGA & III & 2.04 & 0.28 & 0.72 & 1340.89 & 1526.26 & 20.43 & 2.50 & 13.67 \\
\hline
\end{tabular}

\section{Figures}




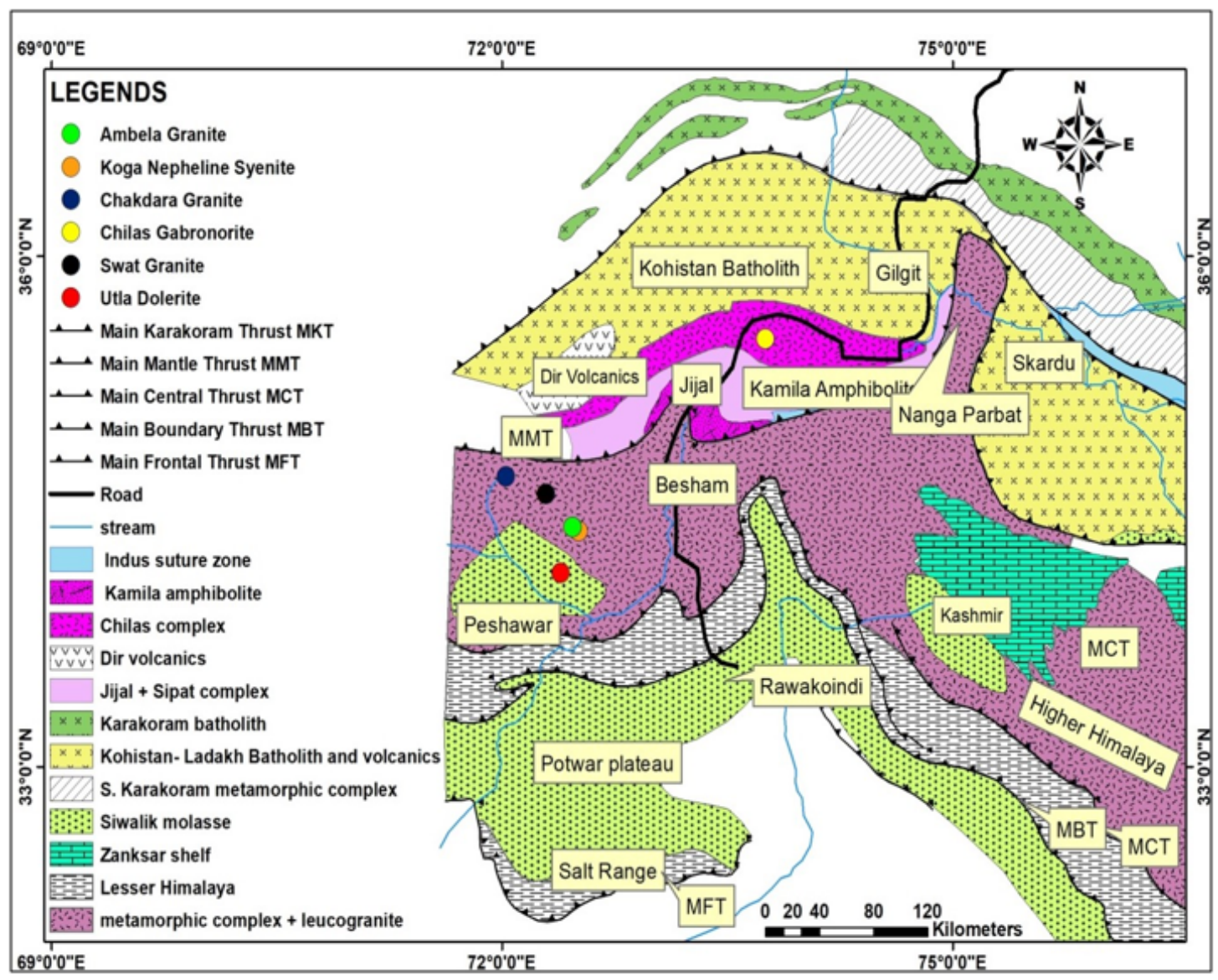

\section{Figure 1}

Geological map of North Pakistan, modified after Searle et al. (1999). Shaded circles show the locations of the collected samples. 


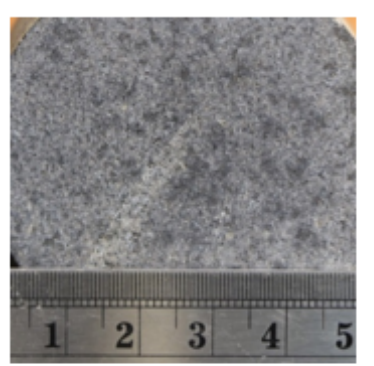

a) Utla Dolerite (UD)

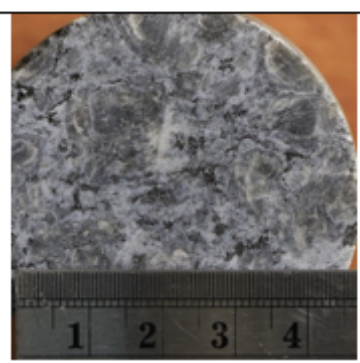

d) Ambela Granite (AG)

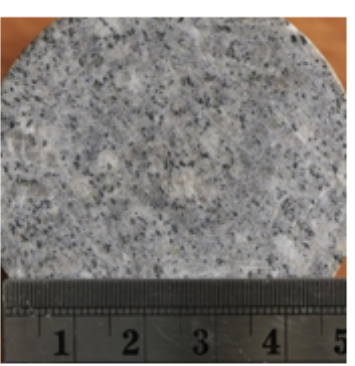

b) Nepheline Syenite (ANS)

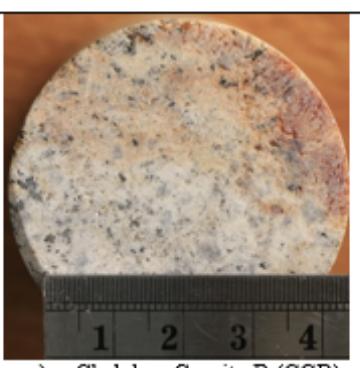

e) Chakdara Granite-B (CGB)
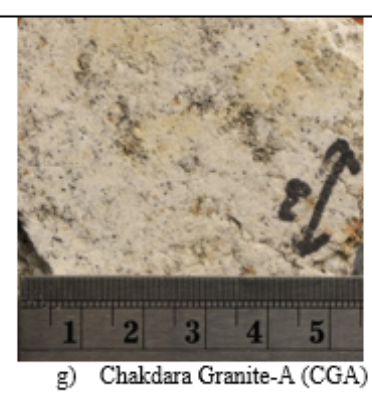

\section{Figure 2}

Photographs of the studied intrusive rocks

g) Chakdara Granite-A (CGA)
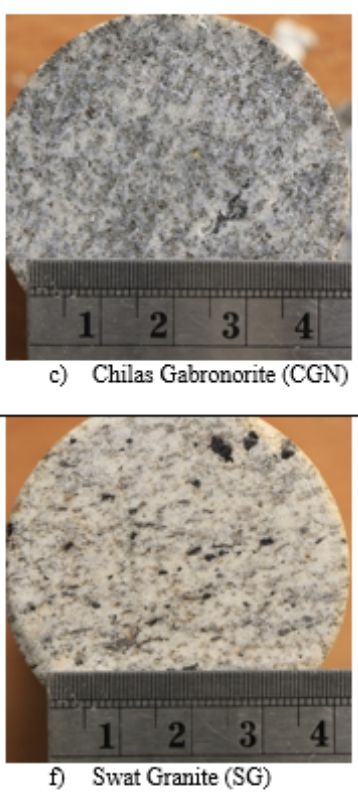


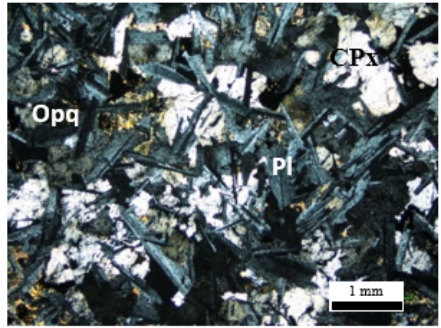

a) Ophitic texture of dolerite (sample UD)

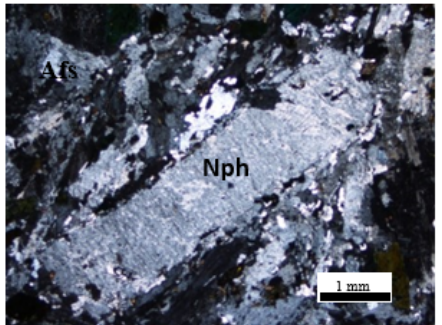

b) Tabular phenocryst of nepheline (sample ANS)
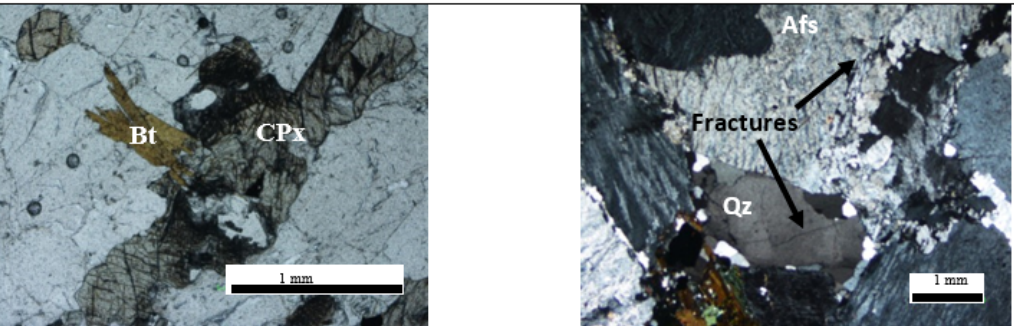

c) Alteration of pyroxene to biotite (sample CGN)

d) Fractures in feldspar and quartz (Sample AG)

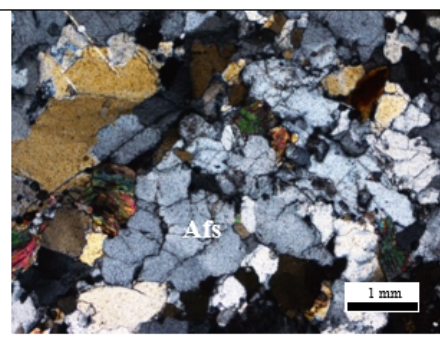

e) Highly fractured alkali feldspar and quartz

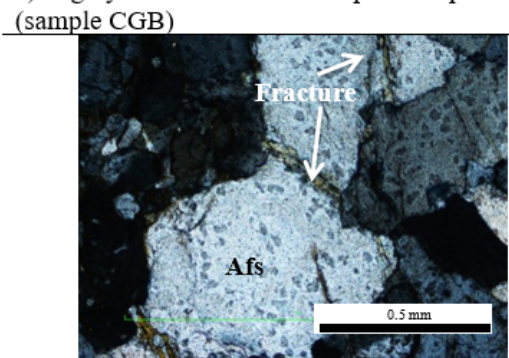

h) Fracture in feldspar (sample CGA)

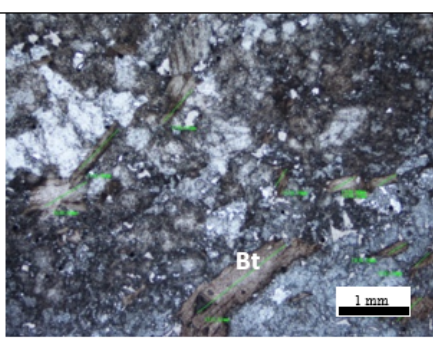

f) Alignment of mica minerals (sample SG)

\section{Figure 3}

Microphotographs of the investigated rocks. Afs= alkali feldspar, Qz= quartz, $\mathrm{Pl}=$ plagioclase, $\mathrm{Bt}=$ biotite, $\mathrm{Opq}=\mathrm{opaque}$ minerals, $\mathrm{Nph}=$ nepheline, $\mathrm{CPx}=$ clinopyroxene, 

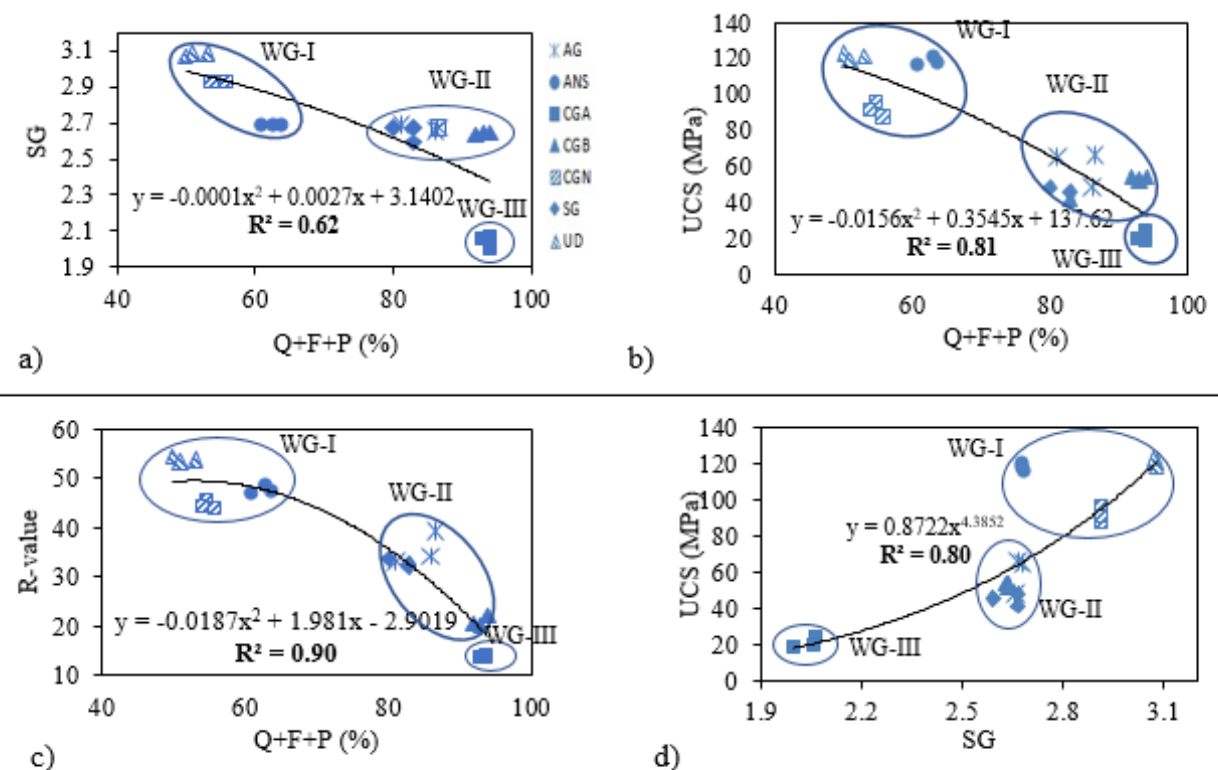

b)

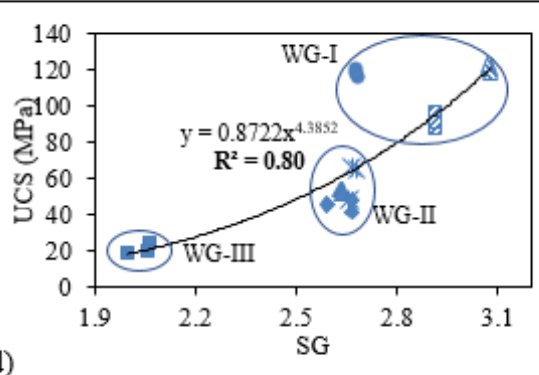

d)

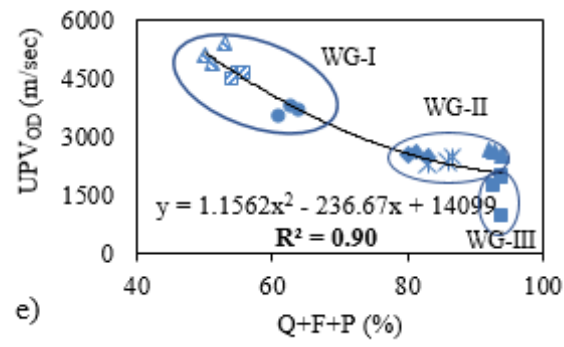

\section{Figure 4}

Correlation plots of (a) Cumulative percentage of Quartz, Feldspar and Plagioclase (Q+F+P) vs Specific gravity(SG) (Polynomial), (b) $\mathrm{Q}+\mathrm{F}+\mathrm{P}$ vs Unconfined compressive strength (UCS)(Polynomial), (c) UCS vs SG, (d) Q+F+P vs R-value (Polynomial), (e) Q+F+P vs Ultrasonic pulse velocity oven-dry (UPV OD) (Polynomial). Symbols given in (a) are the same for all figures. 

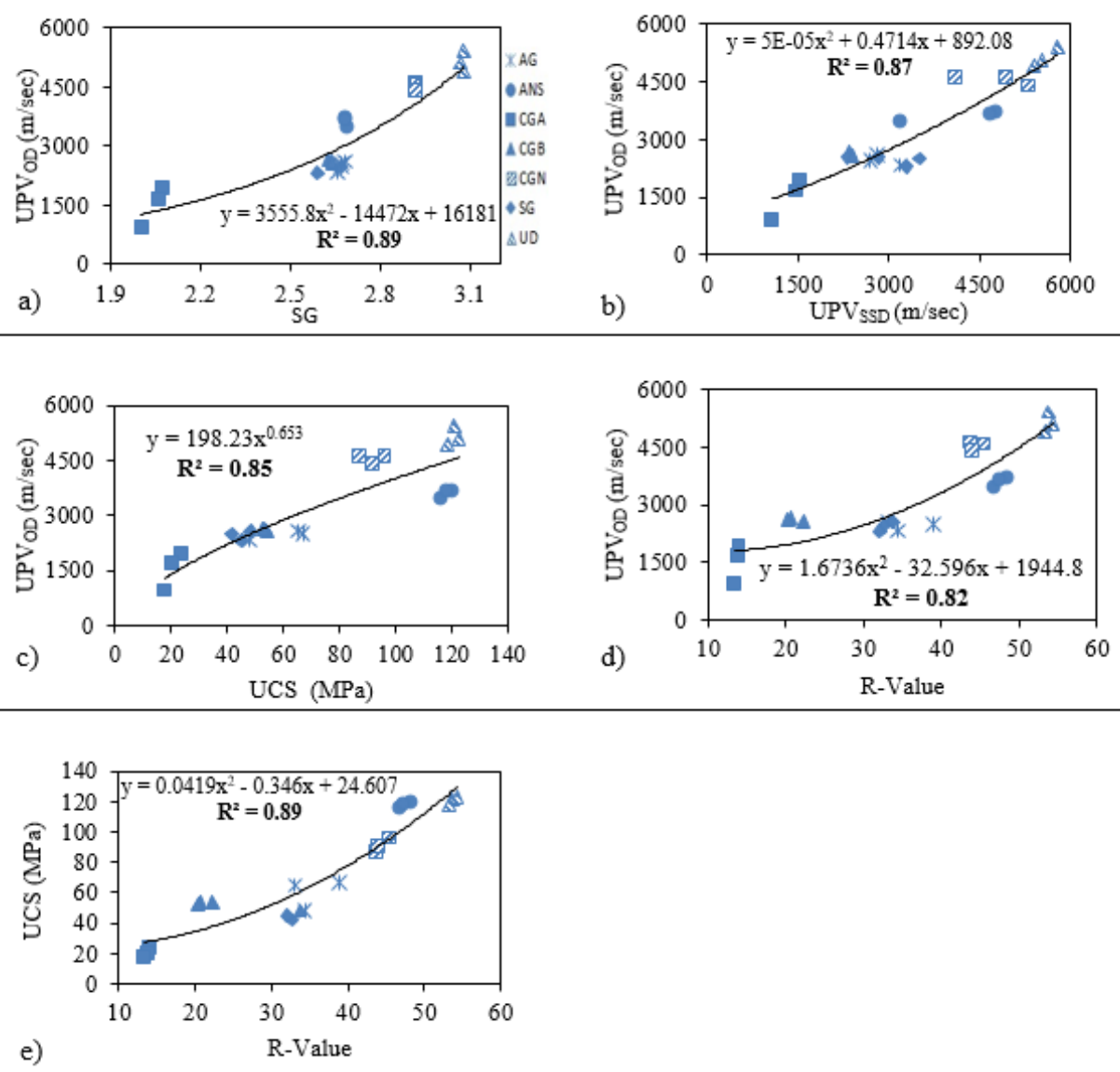

\section{Figure 5}

Correlation plots of (a) Ultrasonic pulse velocity oven-dry (UPV OD) vs Specific gravity (SG)(Polynomial), (b) UPV OD vs UPV SSD (Polynomial), (c) UPV OD vs UCS (Power) (d) UPV OD vs R-Value (Polynomial), (e) UPV OD vs R-Value (Polynomial). Symbols given in (a) are the same for all figures. 


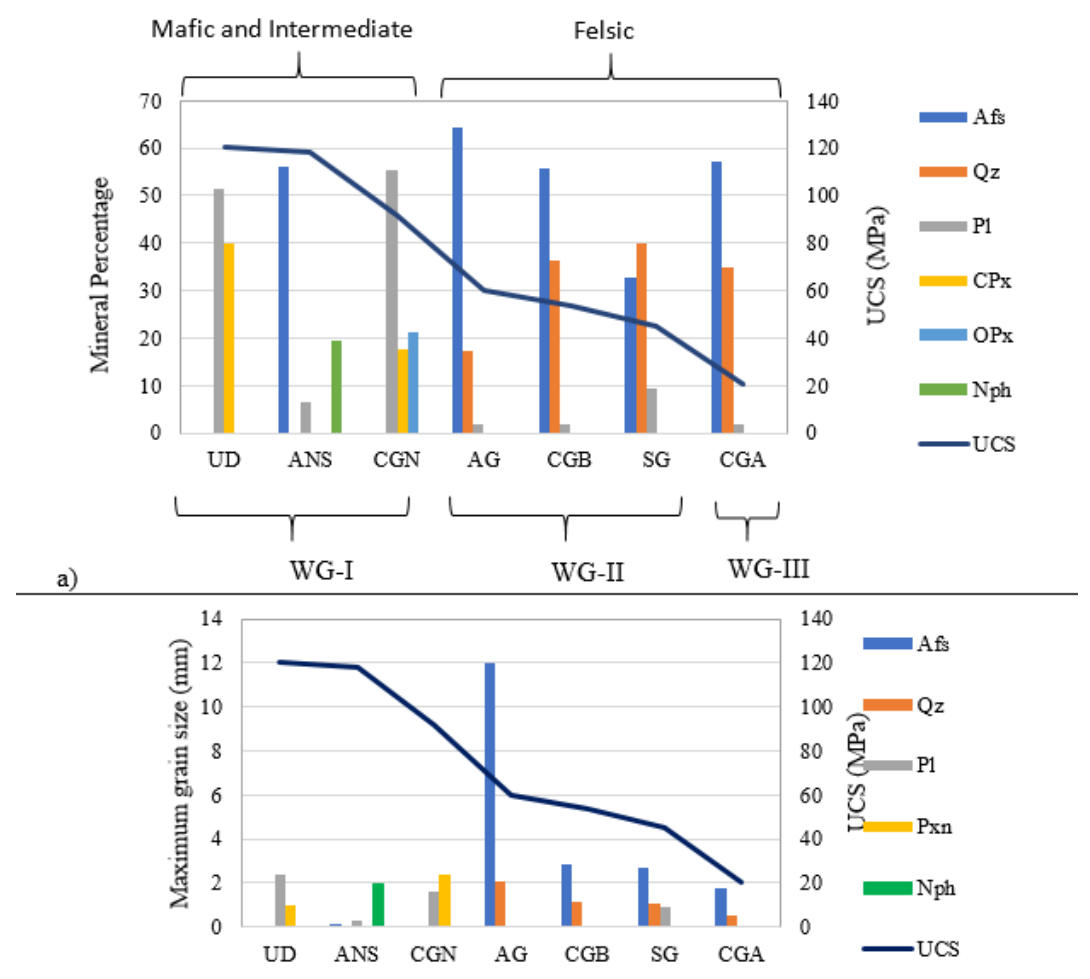

b)

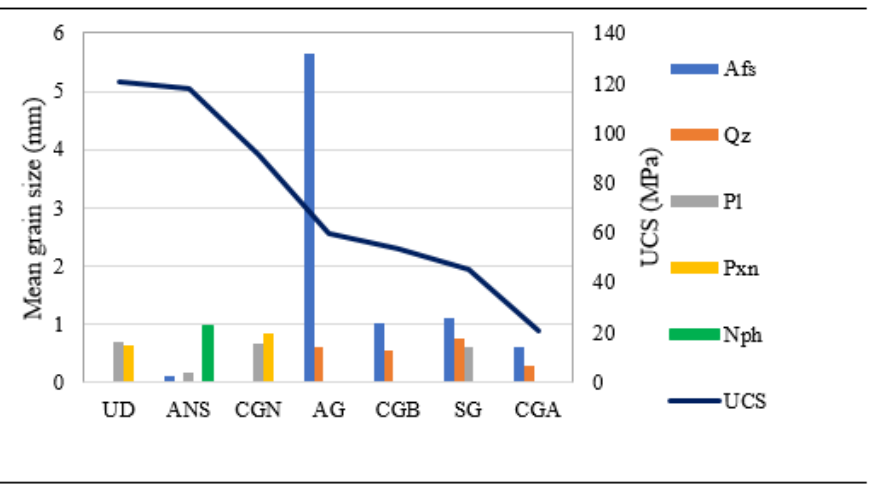

Figure 6

Relationship between the mineral grain size and the uniaxial compressive strength 